\title{
Using Digital Stories to Promote Students' Learning and Understanding of Poems in Secondary School
}

\author{
Yee Bee Choo ${ }^{a, b^{*}}$, Tina Abdullah ${ }^{b}$, Abdullah Mohd Nawi ${ }^{b}$ \\ aInsitute of Teacher Education Tun Hussein Onn Campus, 83009, Batu Pahat, Johor, Malaysia \\ ${ }^{b}$ Language Academy, University Teknologi Malaysia, 81310 UTM Johor Bahru, Johor, Malaysia
}

*Corresponding author: beechoo.yee@iptho.edu.my

\begin{abstract}
In the teaching of literature in secondary school, some teachers prefer the traditional method and this causes students to view literature as a boring subject. In this technological era, technology method such as digital stories have been a powerful tool in teaching and learning that engages both teachers and their students (Robin, 2008). This study investigates the use of digital stories in the teaching and learning of poems in an upper form classroom in Malaysia. In a mixed method study of eleven participants , multiple data were collected through pre-test and post-test, observations, and interviews. The results showed that using digital stories could increase students' understanding, participation and interest in learning the poems as well as promote students' ability in meaning making by involving them in fun and meaningful activities in the classroom. Students were also able to engage themselves in gathering information as well as giving personal response. The findings of the study encourage the teachers to integrate technology in the teaching and learning of literature component especially in the Malaysian secondary school context.
\end{abstract}

Keywords: Digital stories; technology; literature; poems; secondary school

(C) 2017 Penerbit UTM Press. All rights reserved

\subsection{INTRODUCTION}

Today, technology has had a striking impact on the process of communication and learning. The new generation is adept with technology, so teachers could make the best use of technology to support students' learning. In order for classroom instruction to be most productive, it must be open to all modes of communication (Kist, 2000) and digital stories have gained its popularity in second language classrooms where it promotes target language development and formation of socio-cultural identities (Wang \& Zhan, 2010). This study attempts to present the use of digital stories in teaching poems to secondary school students. It examines how digital story can encourage students' understanding, participation and interest when they learn poems in literature lessons. It also investigates their meaning making through their personal response in the literary texts.

\subsection{LITERATURE REVIEW}

Since the year 2000, literature has been incorporated as a tested component in the English language syllabus in the Malaysian secondary school. The aims of the component stated under the section on Language for Aesthetic Purpose (Ministry of Education, 2003) are:

1. to develop in learners the ability to enjoy and appreciate the aesthetic values of the literary works being studied,

2. to inculcate values and broaden learners' outlook, and

3. to express themselves creatively and imaginatively in the target language.

According to Rosenblatt (1978), there are two stances that can be adopted when a reader reads literary texts. The efferent stance will enable the reader to focus on gathering information for the purpose of comprehension while the aesthetic stance engages the reader in living through experience. Rosenblatt explains when reading a literary text aesthetically, the reader chooses to adopt the 'aesthetic stance' that would enable him to engage himself in a more personal meaning making level. Meanwhile, the aesthetic stance would permit focus on 'private meaning making' of the text (Rosenblatt, 1995). This is when the reader is able to go through the meaning making process by relating it to personal experiences, feelings and ideas (Abdullah \& Zainal, 2008). Therefore, when studying literature, students not only need to understand the literary text, but they are also expected to be able to give personal response to the text. When students are able to relate the literary texts to their personal life, the aims which were stated above would be achieved.

Some of the learning outcomes that teachers could accomplish when teaching literature are outlined below. They are used so that students are able to listen to, read and respond to literary works.

a. understanding and telling in one's own words the story and poem heard and read, and giving one's opinion of the text;

b. recognising elements in a story such as characters and setting; 
c. explaining the message the writer is trying to convey and discussing how this relates to one' life;

d. understanding other people's cultures, traditions, customs, and beliefs;

e. reciting poems with feeling and expression. (Ministry of Education, 2003)

In 2010 when introducing the new set of literature component in Malaysia, the Curriculum Development Division advocated another approach for teaching literature by treating it as something light, with an emphasis on enjoyment. The genre of drama and plays was introduced for the first time through this new set of literature component besides poems, short stories and novels. The drama text chosen was "Gulp and Gasp" by John Townsend, and later "Five Short Plays" by Martyn Ford since 2015. This is in line with the learning outcome 3.2 when students engage in dramatising, role-playing, retelling and other activities, they can involve their creativity and imagination in learning literature. It is hoped that through fun-filled and meaningful activities in the literature component, students will gain rich and invaluable experience in using the English language. It also engages students in active learning that requires them to do meaningful learning activities and think about what they are doing (Bonwell \& Eison, 1991).

However, teachers resorted to traditional method in the teaching of literature instead of engaging fun-filled meaningful activities in the classroom. According to Anyachebele, Anyamene, Obumneke-Okeke and Adebola (2011), "literature teachers are not abreast with the strategies that are effective for facilitating learning for students." Literature lessons are mostly taught in the old ways, the traditional ways used in mother-tongue (Zhen, 2012). Some teachers teach literature as a transfer of information and it was found that teachers preferred information-based activities in that they read the story, retell the story, explain, question and give answers to the students (Hwang \& Embi, 2007). This type of activity only engages students in efferent reading as their attention is mainly focused on results from an abstracting-out and analytic structuring of the ideas, information, directions, conclusions to be retained, used or acted on after the reading" (Rosenblatt, 1988), and thus they focusses mostly on the public referents of meaning and ignore the private aspects of meaning making. According to Abdullah (2012), these activities demand the students to read the text in search for information rather than to enjoy the aesthetic value of literary texts.

Sometimes the teachers do not appear to be enthusiastic with what they are teaching thus resulting in students finding it hard to tell whether the subject or the teacher is boring. If the teachers are unable to teach the subject in an interesting way, this will cause students to lose interest in learning literature and thus affect their understanding of literature. In the Malaysian contexts, there have been numerous studies on teachers' approaches and students' perceptions on the teaching and learning of literature, for example, Hwang and Embi (2007), Abdullah and Zainal (2008), and Isa and Mahmud (2012). These researches have revealed that most teachers prefer teacher-centred activities in the literature classroom due to time constraint and students lack interest in reading literary texts that have affected their comprehension. Therefore, it is beneficial for teachers to come up with new strategies in teaching literature so that literature could be taught in a more interesting way rather than only teaching the way they have been so used to. This is to ensure that students are motivated to read and engage in the literary texts.

There are many ways teachers can involve students by conducting lots of interesting and enjoyable activities such as role plays, dramas, quizzes and choral speaking. However, the use of technology has a positive impact in terms of valuable time savings, the simplification of instruction and the enhancement of the learning process (Belias, Sdrolias, Kakkos, Koutiva, \& Athanasios, 2013) and at the same time helping students in the development of certain skills including writing, communication, interaction, collaborative, critical thinking and consciousness (Boyce, 1999).

According to Krashen (1982, 1985), English language learners develop linguistic proficiency gradually, supported by visual aids, text modifications, or authentic learning environments. Technology tool such as digital stories can be effective in teaching as it is a multimedia movie that combines photographs, video, animation, sound, music and sometimes a narrative voice (Roland, 2006). Researchers such as Burmark (2004) and others have found that integrating visual images with written text both enhances and accelerates student comprehension. Teachers who are able to create their own digital stories may find that they can be particularly helpful not only in engaging students in the content but also in facilitating discussion about the topics presented in a story and helping make abstract or conceptual content more understandable (Robin, 2009). A multimedia-rich digital story can serve as an anticipatory set or hook to capture the attention of students and increase their interest in exploring new ideas. Teacher-created digital stories may also be used to enhance current lessons within a larger unit, as a way to facilitate discussion about the topics presented in a story and as a way to make abstract or conceptual content more understandable (Robin, 2008). Significantly, using digital stories allows students to understand the contents in the lesson and increase their interest in learning.

The National Education Blueprint also proposes the use of technology to bring more effective English instruction to students. Technology has the dual advantage of offering personalised learning customised to individual needs and being quickly scalable (Ministry of Education, 2012). In view of the characteristics and advantages of using technology, the Ministry is exploring self-directed online learning, interactive online tutoring and software-based learning guides as seen in Figure 1. It shows the importance of implementing technology in teaching English which is emphasised by the Malaysian Ministry of Education. This is at par with the current technological era as students today are using emerging technologies in their personal lives, where they are constantly in contact with the widely publicised websites such as blogs, wikipedias, podcasts, and social bookmarking tools. They are non separable with technologal gadgets like iPads and smart-phones. They are using them at an ever increasing pace and in ways that are helping to define a new generation of not just information gathering, but information-creating as well (Robin, 2008). 


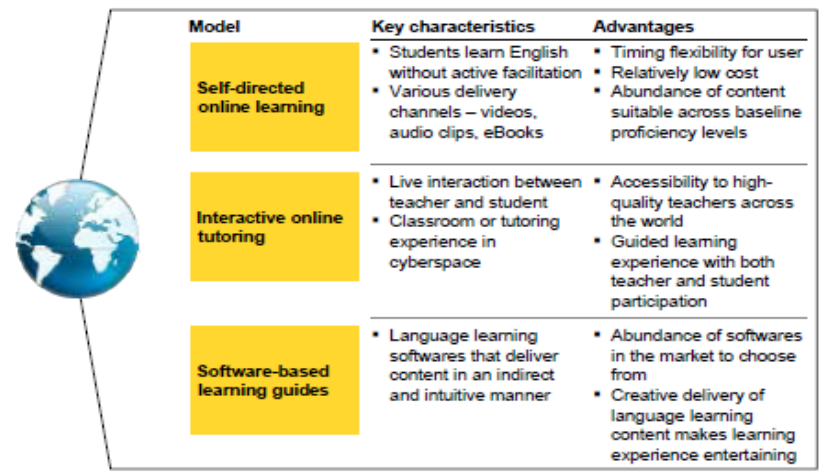

Figure 1 ICT models under consideration for english instruction (Ministry of Education, 2012, p. 4-14)

As a vehicle for creative expression, digital stories is a tool for meaningful technology integration and learning and highly motivating to students (Sadik, 2008). A number of studies have demonstrated the effectiveness of instructional models and techniques for using digital story projects in the second language classroom (e.g., Burmark, 2004; Lannotti, 2004; Yuksel, Robin \& McNeil, 2011, Sukovic, 2014). However, there has been limited amount of studies done on the effectiveness of digital stories in teaching literature within the context of Malaysian secondary classroom. The current study investigates how the creation of digital stories in literature promotes the understanding of students towards poems. This guided the aim of this study to promote the use of digital story to help students to enjoy reading and make meaning from literary texts.

Therefore, the research objectives of this study are to:

1. investigate the use of digital story to help secondary school students to understand poems taught in the literature component.

2. examine to what extent the digital story will enhance teaching and learning literature in the secondary school classroom.

\subsection{METHODOLOGY}

\section{Research Design}

The research adopted a mixed method study that utilised an explanatory sequential design that collects both quantitative and qualitative data. The researcher begins with by conducting a quantitative phase and follows up on a second qualitative phase (Creswell \& Clark, 2011). The qualitative data collection is used to explore important quantitative results with a few participants. The rationale for following up with qualitative result in the second phase is better understand and explain the quantitative results. Its advantage is its two-phase structure makes it straightforward to implement, because the researcher conducts the two methods in separate phases and a single researcher can collect the data alone without the aid of a research team (Creswell \& Clark, 2011).

\section{Research Participants and Instruments}

The participants of this study were from a small upper secondary classroom where eleven of them were selected. These participants were chosen based on purposive sampling as they were the class that was available when the researcher visited the school. The class consisted of 18 students but seven of them were involved actively in sports practice and tournament, so sometimes they were not present when the researcher carried out the intervention. The participants were from a cluster school in an urban area in Johor, Malaysia. They were all boys who were in an average of 17 years old. They could speak English quite well and their proficiency for English was intermediate.

The instruments were pre-test and post-test, observations and interviews. The pre-test and post-test contained the same questions and they consisted of eight multiple choice questions and two open-ended questions to elicit students' personal opinions. The test was checked by two English experts before it was distributed to the students. The time taken for each test was 20 minutes.

The research also applied in-class observations and video recordings of the teaching and learning sessions. Students were observed for their participation and responses given for the poem during the lesson and activities. A focus group interview was carried out after the lesson with three selected students. These students were selected based on their active participation in the class and they were asked five questions as below:

1. Do you like this lesson?

2. What have you learnt today?

3. Which part of the lesson do you like the most? Why?

4. Do you like the video? Which part of the video do you like the most? Why?

5. Does the video help you to understand the poem better? How?

This study involved participant-observation in the role of researcher. The researcher was the teacher of English who taught the participants when the school was visited. Poems prescribed for the literature component were taught and one poem, "The Charge of the Light Brigade" written by Lord Alfred Tennyson, was selected specifically for the discussion of this study. The researcher was able to observe the participants and record their activities during the lesson.

At the beginning of the teaching session, a pre-test was given to gauge the participants' existing knowledge on a poem they had learnt. Then, the researcher taught the students by using a digital story. The digital story for the poem was designed using the software Movie Maker 
which contained some images of soldiers, war and dead bodies since the poem was about a troop of soldiers who were sent to war despite the wrong command given by their captain which led the soldiers to their death. A video clip from YouTube on the documentary of Crimean War was inserted in the digital story to show the history of the war that had happened when the poem was written. The researcher also inserted her own voice in each line of the poem's narration.

Before showing the digital story to the students, the researcher gave some input on the vocabulary used in the poem. Then, the activities carried out were sequencing the events of the poem and writing an email to a friend who was fighting in the war. The sequencing activity was to involve students in information gathering while email-writing aimed to engage students in personal response. The researcher observed the students' participation and their interest in the classroom to find out the effectiveness of the digital story in the lesson. At the end of the teaching session, the students were given a post-test. Then, three students were interviewed and they were selected based on their active participation in the classroom. The interview aimed to find out their perceptions and views towards the use of digital story in literature lessons.

Data from the pre-test and post-test were analysed descriptively through means and standard deviations while data from the interviews, observations and video recordings were thematically analysed, and relevant findings were made salient. All data were triangulated, the process of which will be discussed in the following paragraphs.

\subsection{RESULTS AND DISCUSSION}

For the tests, the eight multiple choice questions were awarded one mark each while the two open-ended questions were awarded two marks each. Table 1 below shows the results of pre-test and post-test.

Table 1 Pre-test and post-test scores

\begin{tabular}{lcc}
\hline & Pre-test & Post-test \\
\hline Mean Score & $60.45 \%$ & $75.18 \%$ \\
Standard Deviation & 9.96 & 1.95 \\
\hline
\end{tabular}

Based on the above table, the mean score for the pre-test was $60.45 \%$ and post-test was $75.18 \%$ and it showed an increase of $14.73 \%$. The multiple choice questions tested their understanding of certain words such as the meaning of "scared" and meaning of a few lines in the stanza. A question on prediction, for example, "What happened to the soldiers in the end" was asked and the increased mean showed that the students improved in their understanding of the poem after they were exposed to digital story.

The two open-ended questions were as follows:

1. Would you like to be a soldier? Why?

2. If you were a soldier, will you obey a command that is a mistake? Why?

As for the answers given for the open-ended questions in the pre-test, it was found that only three out of eleven students wrote the answers for the first question while none of them answered the second question. However, the post-test showed that eight students were able to give their opinions for the first question and five students answered the second questions. This showed that more students could answer the questions instead of leaving a blank on the spaces. Most of their answers for the first question were "Yes, I would like to be a soldier because I want to protect my country", "Yes, I want to become brave" and other similar answers. As for the second question, their answers were "Yes, soldiers must be obedient ad follow the command without questioning", "Yes, we must follow the commander's order as we're in an army" and other acceptable answers.

The increased mean score in the post-test showed that students had improved in their understanding of poem. Wiggins and McTighe (1998) emphasised that good activities develop deep understanding of the important ideas to be learned. To do this, the activities must be designed around important learning outcomes and promote thoughtful engagement on the part of the students. When the students think about what they are learning, this promotes active learning (Bonwell \& Eison, 1991). Digital stories are effective to engage students in active learning.

Students' answers to the tests also showed they adopted the efferent stance by gathering information for comprehension and aesthetic stance to engage their own personal meaning (Rosenblatt, 1978). However, the personal responses for the open-ended questions in the test were quite limited as the test required them to answer in sentence level. So more personal responses could be found through their other activity as in email-writing where they were required to write their personal response in paragraphs which would be discussed later.

As for the analysis of the qualitative data from observations and interviews, the themes emerged were as follows:

\section{Understanding of Poem}

After showing the digital story, the researcher asked for students' understanding regarding certain vocabularies in the poem, the students were able to tell the meaning of the words. For example, they answered 'attack' for the word 'charge', 'soldiers' for 'light brigade', and so forth. In sequencing the events of the poem, the students were divided into five groups. Four out of five groups of students were able to sequence the poem correctly. They were able to begin the sentence with "Due to miscommunication, the commander of the Light Brigade made a mistake" and ended the poem with "We should admire these soldiers' courage and sacrifice". Though these two sentences were not mentioned in the poem, the students were able to sequence the poem correctly, this suggests that they understood the poem. From the interview, the three students commented that the digital story helped them to understand the meaning of the poem and it contained a lot of details about the poem.

As supported by Roland (2004) and Robin (2006), digital story could enhance students' understanding as it combined images, video, sound and music that helped the students to comprehend the content or concept of a course. In this study, the students were able to understand 
the meaning of the words and the story of the poem after they were exposed to digital story. This shows digital story could enhance their understanding.

\section{Improvement in English}

During the email-writing activity, the students wrote their messages in English. Some of them asked the researcher for spelling of the words or their friends told them the spelling. Some of them were able to use alternative words in English, for example, they used the words 'battle' instead of 'war', and 'courageous' instead of 'brave'. In the interview, all the three students agreed that they could improve their English when they were asked "What have you learnt today?" They gave the following responses:

P1: I learnt more vocabulary as there are more details given.

P2: I improve my English on how to give opinions.

P3: I learnt how to answer in the examination.

The students' feedback to the interview question suggests that when they have positive perceptions in learning the poem, it helps them to improve their English. As supported by Krashen (1982, 1985), English language learners develop linguistic proficiency gradually, supported by visual aids, text modifications, or authentic learning environments. This proves true when the students were exposed to the targeted language in an authentic environment through digital story, they learnt English gradually and this could improve their English.

\section{Increased Participation}

Based on the observations in the classroom and the review of video recording, the students paid full attention when they watched the digital story. They repeated certain words that were narrated in the poem. They giggled among themselves when they found the narrator's voice was funny. This shows they gave their attention to the digital story.

Their participation in the classroom was also active. When they did the sequencing and email-writing activities, they did not hesitate to ask questions to the teacher and all of them did the exercises immediately and handed the sequencing exercises and email on time. Some of them might have problems in using English to express their views and opinions as they took more time to handle their work. However, with the help from their peers, they were able to complete the tasks given. The interaction and collaboration among the students showed that the use of digital story develops their skills in writing and this further supports its effectiveness (Boyce, 1999).

\section{Engagement in Personal Response}

The email-writing was an individual work and most of the students wrote the email to their own classmates. They enjoyed writing the email as they could show their creativity in giving personal response and they anticipated the responses given by their classmates when the teacher read out their email responses. Here is an example of an email written by one of the students:

"Hello, Dan. I hope you are in the pink of health. I felt sorry to hear that your country is having war with another country. You have to fight bravely and courageously for your country. You have to be strong, Dan. I hope you are safe in the war."

Another student also wrote the following:

"Dear Sarif, How are you? I want to give you moral support and encouragement as you will fight in the war. Please don't give up and keep it up. Try to do the best in the war and don't scare of death because you must fight for your country."

Most of them gave encouraging words such as "don't give up", "protect your country", "be strong in facing difficulties" and "be in a team to fight" in their emails. When the teacher read aloud their emails, they were interested to know who was the writer and to whom it was written. It could be seen from their facial expressions and reactions that they enjoyed the email-writing.

Their interview responses towards the activity of email-writing were given as below:

P1: Writing email is interesting as I have a lot of ideas.

P2: I learnt how to encourage our friends who are in the war.

P3: It is a new way of learning literature in a fun way.

According to Rosenblatt (1995), the personal response or the aesthetic stance permit the students to focus on 'private meaning making' of the text. Through email-writing, the students were given the opportunity to express their feelings about the war and gave opinions to their peers on how and what they should do to remain strong during the fight in the war. This creates meaning-making on their part as the reader of the poem.

\section{Increased Interest}

Throughout the activities, the students showed interests in the lesson by giving answers and comments when the researcher asked them questions. When the researcher read out their response, they were eager to listen to their friends' responses and they laughed out loud when they heard something funny. For example, one of the students wrote the following:

"Dear my love, you know I love you just like Darth Vader. I want you to know that I'll never give up on you. EVER!

So I want to ask you a favour. If you want to go on a war, don't give up. And if you want to die, just die. I'll wait for you in the heaven, my love. And we will be together and forever."

The interview also revealed that all the three participants gave positive responses towards the use of digital story. They gave the following comments:

P1: I like the video because it is nice and simple.

P2: The narrator's voice is funny.

P3: I like it because it is easy to understand. 
When asked which part of the digital story they enjoyed the most, the first participant preferred the introduction part with the sound effects, the second liked the pictures and soundtrack and the third liked the meaning given for each stanza of the poem that was shown in the digital story.

The observations and interview had shown that the students enjoyed the literature lesson, they develop their interest in literature when they could share ideas. Strommen and Mates (2004) supported that readers learn through social interaction with other readers, this type of reading is entertaining and stimulating. The students enjoyed reading more when they could engage in discussion. Therefore, teachers should engage students in group discussion and sharing of ideas in the teaching of literature.

The use of digital story also helps students to become active learners when they can construct meaning from the literary texts. They learnt the words in the poem and they were able to use those words in their writing. They could respond by giving comments such as "don't give up" to encourage their friends to be strong and persistent in the war. They could produce their own personal response by connecting the texts to issues in their lives and describing what they experience as they read. Rather than waiting for their teacher to give them the answers, they interact with their friends for interpretation of the texts and show active participation in the classroom. They also showed positive perception towards the use of digital stories to help them understanding the poem and they could learn literature in a fun and meaningful way as they engage with the literary texts actively. This is supported by Sukovic (2014) that digital story has positive effects on students' skills, engagement with learning and social skills.

\subsection{CONCLUSION}

The findings of this study show the advantages of using digital story to enhance the teaching and learning of literature. This approach not only helps students to understand literature in a more effective way, but it also develops their meaning making skills through an enjoyable interactive learning experience in class. Digital stories can be a potent learning experience that encompasses much of what society hopes that students will know and be able to perform in the $21^{\text {st }}$ century (Robin, 2009). It provides teachers with great opportunities to integrate technology into their classrooms. Therefore, it is an invaluable tool in the teaching and learning experiences.

\section{References}

Abdullah, T., \& Zainal, Z. (2008). Faces of Literature Instruction. Retrieved from https://teknologimalaysia.academia.edu/TinaAbdullah/Papers

Abdullah. T. (2012). Engaging Learners In Meaning Making Of A Short Story Through Reading And Group Discussion. (Unpublished doctoral dissertation). Universiti Teknologi Malaysia, Skudai, Malaysia.

Anyachebelu, F.E., Anyamene, A., Obumneke-Okeke, I.M. , \& Adebola, H.E. (2011). Teachers' Perceptions Of Effective Strategies For Teaching Literature To Enhance Students' Learning. Journal of Emerging Trends in Educational Research and Policy Students (JETERAPS), 2(4), $261-264$.

Belias, D., Sdrolias, L., Kakkos, N., Koutiva, M., \& Athanasios, K. (2013). Traditional Teaching Methods Vs Teaching Through The Application Of Information And Communication Technology In The Accounting Field: Quo vadis? European Scientific Journal, 9(28), 73-101.

Bonwell, C.C., \& Eison, J. A. (1991). Active Learning: Creating Excitement In The Classroom. ASHE-ERIC Higher Education Report No. 1. Washington, D.C.: The George Washington University, School of Education and Human Development.

Boyce, G. (1999). Computer-Assisted Teaching And Learning In Accounting: Pedagogy Or Product? Journal of Accounting Education, 17,191-220.

Burmark, L. (2004). Visual Presentations That Prompt, Flash \& Transform. Media and Methods, 40(6), 4-5.

Hwang, D., \& Embi, M. A. (2007). Approaches Employed By Secondary School Teachers To Teaching The Literature Component in English. Jurnal Pendidik dan Pendidikan, 22, 1-23.

Isa, N. H., \& Mahmud, C. T. (2012). Literary Texts For Malaysian Secondary Schools: Needs Versus Policy. International Journal of Humanities and Social Science, 2(7), 76-86.

Kist, W. (2000). Beginning to Create The New Literacy Classroom: What Does The New Literacy Look Like? Journal of Adolescent \& Adult Literacy, 43(8), 710-718

Krashen, S. D. (1982). Principles and Practice In Second Language Acquisition. Oxford: Pergamon Press.

Krashen, S. D. (1985). The input hypothesis. Harlow: Longman.

Lannotti. E. (2004). How to Make Crab Soup: Digital Storytelling Projects For ESL Students. In Transit, 10-12. Retrieved from http://ctl.laguardia.edu/journal/pdf/InTransit_v1n1_DigitalStorytellingESL.pdf

Merriam, S.B. (2002). Qualitative Research In Practice: Examples For Discussion And Analysis. San Francisco: Jossey-Bass.

Ministry of Education, Malaysia. (2003). Curriculum Specification for English Form 4. Putrajaya: Curriculum Development Centre.

Rosenblatt, L.M. (1995). Literature as Exploration. New York: Modern Language Association

Ministry of Education, Malaysia. (September, 2012). Preliminary Report: Malaysia Education Blueprint 2013-2025. Putrajaya: Ministry of Education.

Robin, B. (2008). The Effective Uses Of Digital Storytelling As A Teaching And Learning Tool. Handbook of Research on Teaching Literacy through the Communicative and Visual Arts (Vol. 2).

Robin, B. R. (2009). Digital Storytelling: A Powerful Technology Tool For The 21st Century Classroom. Theory Into Practice, 47(3), 220-228. DOI: $0.1080 / 00405840802153916$

Roland, C. (2006). Digital stories in the classroom. School Art, 105(7), 26.

Rosenblatt, L.M. (1988). Writing and reading: The Transactional Theory. Center for the Study of Writing: Technical Reports. Illinois: University of Illinois.

Sadik, A. (2008). Digital Storytelling: A Meaningful Technology-Integrated Approach For Engaged Student Learning. Educational Technology Research \& Development, 56(4), 487-506.

Strommen, L., \& Mates, B. (2004). Learning to Love Reading: Interviews With Older Children And Teens. Journal of Adolescent and Adult Literacy, 48(3), 188200 .

Sukovic, S. (2014). iTell: Transliteracy and Digital Storytelling. Australian Academic \& Research Libraries, 45(3), 205-229.

Wang, S., \& Zhan, H. (2010). Enhancing Teaching And Learning Through Digital Storytelling. International Journal of Information and Communication Technology Education, 6(2), 76-87.

Wiggins, G., \& McTighe, J. (1998). Understanding by design. Merrill Education/ASCD College Textbook Series.

Yin, R. K. (2009). Case Study Research: Design And Methods (4th ed.). Thousand Oaks, CA: Sage.

Yuksel, P., Robin, B., \& McNeil, S. (2011). Educational Uses Of Digital Storytelling Around The World. In M. Koehler \& P. Mishra (Eds.), Proceedings of Society for Information Technology \& Teacher Education International Conference 2011 (pp. 1264-1271). Chesapeake, VA: Association for the Advancement of Computing in Education (AACE).

Zhen, C. (2012). Characteristics and Strategies Of Literature Teaching in the EFL context in China. International Journal of Electronics and Communication Engineering, 5(3), 35-43. 